\title{
KEMANUNGGALAN DALAM YOHANES 15:7 SEBAGAI MISI KONTEKSTUAL KEPADA PENGANUT KEJAWEN
}

\author{
Dicky Dominggus \\ Sekolah Tinggi Teologi Injil Bhakti Caraka Batam \\ Dicky.Dominggus@sttibc.org
}

\begin{abstract}
This article discusses of the oneness in John 15:7 as a contextual mission attempt to the Kejawen practitioners. In John 15:7 is explained that if humans are in God and God is in humans, then all that people want will be fulfilled. In the Kejawen teaching, there is also an understanding of oneness, called Manunggaling Kawula Gusti. The concept is also the unification between man and God. The unification of Man with God in this concept through the stages of changing human life. From that definition, the legacy in John 15:7 has similarities with those in the Manunggaling Kawula Gusti concept. For this reason, both of these can be compared by looking at the similarities and differences between the two. The result obtained from this comparison can be used as a contextualization mission to the Kejawen believers. The method used in this study is a qualitative research with the approach of literature study and comparisons.
\end{abstract}

Keywords: Manunggaling Kawula Gusti; Kejawen; John 15:7

Abstrak. Artikel ini membahas kemanunggalan di dalam Yohanes 15:7 sebagai upaya misi kontekstual kepada penganut ajaran Kejawen. Di dalam teks ini dijelaskan apabila manusia di dalam Tuhan dan Tuhan di dalam manusia, maka semua yang dikehendaki manusia akan dipenuhi. Di dalam ajaran Kejawen juga terdapat pemahaman tentang kemanunggalan yaitu Manunggaling Kawula Gusti. Di dalam konsep ini juga penyatuan antara manusia dengan Tuhan. Penyatuan manusia dengan Tuhan di dalam konsep ini melalui tahapan perubahan hidup manusia. Dari definisi yang ada, Kemanunggalan di dalam Yohanes 15:7 memiliki kesamaan dengan yang ada di Konsep Manunggaling Kawula Gusti. Untuk itu, kedua hal ini dapat dilakukan perbandingan dengan melihat persamaan dan perbedaan di antara keduanya. Hasil yang diperoleh dari perbandingan ini dapat digunakan sebagai misi kontekstualisasi kepada penganut kepercayaan Kejawen. Metode yang digunakan dalam penelitian ini merupakan metode penelitian kualitatif dengan pendekatan studi pustaka dan komparasi (perbandingan).

Kata-kata Kunci: Manunggaling Kawula Gusti; Kejawen; Yohanes 15:7

Pada dasarnya, manusia merupakan makhluk yang terbatas. Artinya, manusia tidak dapat hidup tanpa adanya bantuan dari pihak lain yakni sesama manusia dan Tuhan. Keterbatasan inilah yang menuntut setiap orang harus memperhatikan hubungan dengan sesama terlebih khusus hubungannya dengan Tuhan. 
Yohanes 15:7 merupakan teks yang menuliskan tentang hubungan manusia dengan Tuhan dalam bentuk kemanunggalan. Yohanes 15:1-8 memberikan analogi Tuhan sebagai pokok anggur dan manusia sebagai ranting-rantingnya. Secara khusus di dalam Yohanes 15:7 tertulis "Jika kamu tinggal di dalam aku dan firman-ku tinggal di dalam kamu, mintalah apa saja yang kamu kehendaki, dan kamu akan menerimanya." Secara tersirat, teks ini menunjukkan adanya hubungan timbal balik antara manusia dengan Tuhan akibat yang diperoleh dari hubungan tersebut. Tenney menuliskan teks ini berbicara tentang hubungan Yesus dengan orang percaya. Baginya, orang percaya yang hidup di dalam Tuhan dan juga sebaliknya akan memiliki kehidupan yang berbuah (Tenney, 2003). Pendapat Tenney menunjukkan bahwa hal berbuah merupakan hasil dari ketaatan orang percaya dalam membangun hubungan dengan Tuhan.

Kepercayaan Kejawen memiliki pemahaman tentang kemanunggalan manusia dengan Tuhan yang terdapat dalam konsep Manunggaling Kawula Gusti. Pada dasarnya konsep ini merupakan penyatuan antara manusia dengan Tuhan. Penyatuan yang dimaksudkan di mana manusia bersatu dengan Tuhan dan diwujudkan dalam kehidupan sehari-hari.

Contoh nyata dari konsep Manunggaling Kawula Gusti adalah pengabdian Abdi Dalem Keraton Yogyakarta. Ada beberapa alasan mengapa abdi dalem mau mengabdikan diri kepada Keraton. Alasan tersebut antara lain untuk memperoleh ketentraman hidup, berkah, 
melestarikan budaya, hingga meneruskan orang tua (Sudaryanto, 2018). Di balik motivasi yang dimiliki, bentuk kemanunggalan abdi dalem dapat dilihat dari sikap mereka kepada Sultan memiliki gelar Khalifatullah, yang berarti wakil Tuhan (Haryanto, 2013). Sultan merupakan gambaran dari Tuhan yang kelihatan. Pengabdian abdi dalem adalah bentuk kemanunggalan dengan Tuhan. Artinya, pengabdian di keraton merupakan bentuk horizontal dari kemanunggalan manusia dengan Tuhan secara vertikal.

Jika memang demikian, kemanunggalan seperti apa yang di maksudkan dalam Konsep Manunggaling Kawula Gusti? Apakah memungkinkan seseorang bersatu dengan Tuhan? Bagaimana jika dibandingkan dengan kemanunggalan di dalam Yohanes 15:7? Apakah persamaan dan perbedaan diantara keduanya?

Tulisan ini bermaksud membandingkan konsep kemanunggalan dalam Yohanes 15:7 dengan Konsep Manunggaling Kawula Gusti. Persamaan dan perbedaan keduanya kiranya dapat dijadikan sarana misi kontekstual kepada para penganut Kejawen.

\section{METODE}

Metode yang digunakan dalam penelitian ini adalah kualitatif yaitu metode penelitian yang digunakan untuk meneliti kondisi objek yang alamiah di mana peneliti adalah instrumen kunci (Sugiyono, 2016). Teknik pengambilan datanya adalah studi pustaka, yaitu serangkaian kegiatan yang berkenaan dengan metode pengumpulan data pustaka, membaca, 
mencatat serta mengolah bahan penelitian (Supriyadi, 2016). Sumberinformasi dalam kajian studi pustaka ini diperoleh dari dari media cetak (buku, jurnal, koran dan majalah), media elektronik (internet) yang membahas tentang konsep Manunggaling Kawula Gusti dan tafsiran Yohanes 15:7.

Langkah-langkah penelitian yang ditempuh adalah sebagai berikut: Pertama, mengkaji kemanunggalan di dalam teks Yohanes 15:7. Kedua, mengkaji kemanunggalan dalam konsep Manunggaling Kawula Gusti. Ketiga, mencari persamaan dan perbedaan di antara keduanya agar dapat dijadikan jembatan untuk penjangkauan kepada ajaran Kejawen.

\section{HASIL}

\section{Kemanunggalan dalam Yohanes 15:7}

Yohanes membagi teks Yohanes 15:7 ke dalam dua bagian. Bagian pertama terdiri dari frase "Jikalau kamu tinggal di dalam Aku dan Firman-Ku tinggal di dalam kamu." Dan bagian kedua terdiri dari frase "Mintalah apa saja yang kamu kehendaki, dan kamu akan menerimanya." Untuk itu, perlu penyelidikan dari masing-masing bagian yang ada.

\section{Kemanunggalan Manusia dengan Tuhan}

Pada bagian ini ada dua hal penting yakni manusia tinggal di dalam Tuhan dan juga sebaliknya, Tuhan tinggal di dalam Manusia. Kedua hal ini merupakan hal yang saling berkaitan dan tidak terpisahkan. Carter dkk menuliskan gambaran yang digunakan oleh Yohanes merupakan 
kesatuan antara orang percaya dengan Kristus di mana dalam hubungan ini terdapat kekuatan dan pemeliharaan Tuhan (Carter, Wredberg, Platt, Akin, \& Merida, 2017). Carter dan Wredberg melihat teks Yohanes 15:7 sebagai hubungan timbal balik yang memiliki manfaat untuk manusia.

Kata "tinggal" dari kedua bagian menggunakan kata meinete (manusia tinggal di dalam Tuhan) dan meine (Firman-Nya di dalam manusia). Kedua kata ini memiliki bentuk aorist subjuctive aktif yang menyatakan sebuah pekerjaan yang pernah terjadi dan berlangsung berulang kali (Wenham, 2003). Jika dilihat dari bentuknya, maka "tinggal" yang dimaksudkan di sini dapat terjadi berulang kali. Artinya, manusia dapat tinggal di dalam Tuhan melalui proses yang panjang. Begitu juga sebaliknya, Firman Tuhan dapat tinggal di dalam hidup seseorang melalui proses dan terjadi berulang kali.

Frase "Jika kamu tinggal di dalam aku" merupakan gambaran seharusnya bagaimana manusia tinggal di dalam Tuhan. Klink melihat manusia dapat tinggal di dalam Tuhan dengan adanya intimasi, hubungan yang berkualitas seperti Yesus dan murid-muridnya (Klink, 2016). Jadi, arti tinggal pada bagian ini bukan sekedar berada di dalam Tuhan, melainkan juga sebuah kondisi yang terjadi berulang kalli sehingga adanya hubungan yang intim antara manusia dengan Tuhan.

Membangun hubungan yang intim dengan Tuhan dapat dilakukan dengan berbagai macam cara disiplin rohani. Disiplin berdoa, berpuasa, membaca Firman, bersaat teduh, dan berbagai macam disiplin lainnya. 
Whitney mengemukakan bahwa kehidupan orang Kristen merupakan kehidupan rohani yang memerlukan disiplin agar dapat bertumbuh ke arah menjadi seperti Kristus (White, 2011).

Frase "Firman-Ku tinggal di dalam kamu" merupakan gambaran di mana Firman Tuhan tinggal dalam hidup manusia. Burge melihat seseorang yang memelihara Firman Tuhan merupakan ekspresi mendemonstrasikan kasih Allah kepada dirinya (Burge, 2009). Artinya, hidup di dalam Firman Tuhan merupakan bukti nyata seseorang menyaksikan kasih Allah.

Dengan demikian, bagian pertama dapat dipahami dengan arti Jika kamu tinggal di dalam Aku dan Firman-Ku tinggal di dalam kamu. Bagian ini menunjukkan adanya hubungan timbal balik atau kemanunggalan manusia dengan Tuhan. Manusia tinggal di dalam Tuhan dengan berbagai macam disiplin rohani. Begitu juga sebaliknya, Firman Tuhan tinggal di dalam manusia dan mengubah kehidupan manusia. Namun pada dasarnya, kedua hal ini merupakan sebuah paket yang tidak terpisahkan dan merupakan keadaan yang terjadi berulang-ulang kali.

\section{Dampak dari Kemanunggalan}

Pada bagian ini terdapat dua bagian penting yakni janji (mintalah apa saja yang kamu kehendaki) dan jawaban (dan kamu akan menerimanya). Sama seperti sebelumnya, kedua hal ini merupakan dua hal yang saling berkaitan. Namun, kedua hal ini (janji dan jawaban) 
merupakan dampak dari adanya hubungan timbal balik antara manusia dengan Allah.

Frase "Mintalah apa saja yang kamu kehendaki" merupakan janji dari Tuhan setelah manusia tinggal di dalam Tuhan dan Firman Tuhan di dalam kehidupannya. Henry menuliskan orang yang sudah hidup di dalam Tuhan dan Firman Tuhan tinggal di dalam hidupnya, tidak akan meminta sesuatu yang baik dari Allah karena hubungan intim yang dimilikinya sudah lebih dari cukup (Henry, 2008). Henry melihat bahwa intimasi hubungan Allah dengan manusia jauh melebihi kebutuhan manusia. Hal yang sama dikemukakan Bruner yang menilai bagian ini merupakan janji yang luar biasa di mana Yesus menginginkan murid-murid-Nya untuk memikirkan hubungan yang dekat dengan-Nya daripada semua kebutuhan jasmani yang ada (Bruner, 2012). Meskipun bagian ini merupakan janji, hubungan timbal balik antara manusia dan Tuhan adalah yang terpenting dari semua kebutuhan yang ada.

Frase "Dan kamu akan menerimanya" merupakan jawaban yang diberikan dari janji pada bagian sebelumnya. Yohanes menggunakan kata Yunani genesetaiyang berarti akan menerima. Kata ini berada dalam bentuk future indikatif middle yang merupakan sebuah pekerjaan yang akan terjadi pada waktu yang akan datang (Wenham, 2003). Dengan demikian, Yohanes menuliskan bagian ini untuk menjelaskan bahwa seseorang memiliki keintiman dengan Tuhan akan menerima hal-hal yang dikehendakinya. 
Dengan demikian, bagian ini merupakan kelanjutan dari bagian sebelumnya. Artinya, janji dan jawaban yang ada di bagian ini merupakan bila seseorang memiliki keintiman dengan Allah. Meski demikian, orang yang sudah memiliki keintiman akan melihat semuanya sudah lebih dari cukup. Dengan kata lain, seseorang yang mengejar keintiman dengan Allah, kebutuhan jasmaninya akan senantiasa tercukupi. Hal ini memiliki kesejajaran dengan teks "Carilah dahulu kerajaan Allah dan kebenaranNya, maka semuanya itu akan ditambahkan kepadamu" (Matius 6:33).

\section{Kemanungalan dalam Konsep Manunggaling Kawula Gusti}

Pada dasarnya, pengabdian abdi dalem didasari oleh konsep Manunggaling Kawula Gusti yang berasal dari pemahaman Kejawen (Hadiwijaya, 2010). Konsep ini memiliki arti penyatuan antara manusia dengan Tuhan; manusia sebagai ciptaan ingin menyatu dengan Tuhan sebagai pencipta. Soedjarwo Wreksosoehardjo menuliskan di dalam konsep ini manusia tidak hanya menjalankan perintah agama dan mengindahkan perintah Tuhan tetapi juga sangat menginginkan untuk menyatu dengan zat yang menciptakan (Wreksosoehardjo, 2009).

Konsep Manunggaling Kawula Gusti memiliki dua hubungan yang berkaitan yakni hubungan vertikal dan hubungan horizontal. Hubungan vertikal menjelaskan tentang menyatunya roh manusia dengan Tuhan sedangkan hubungan horizontal diwujudkan dengan sikap memberikan diri untuk mengabdi kepada raja atau hal-hal yang berkaitan dengan 
kemajuan kerajaan (Soesilo, 2004). Inilah yang menjadi dasar ketika seorang abdi dalem mengabdi kepada raja maka sama juga dengan mengabdi pada Tuhan. Bagi abdi dalem, mengabdi kepada raja merupakan sebuah kehormatan besar (Kresna, 2014). Oleh karena itu, ketika abdi dalem menerima upah yang jauh dari layak, hal ini tidak menghalangi ketulusan pengabdian yang telah dilakukan.

Lalu apa maksud dari konsep Manunggaling Kawula Gusti sebagai penyatuan antara Tuhan dengan manusia? Apakah hanya sekedar penyatuan sifat atau zat yang ada? Untuk dapat memahami konsep ini lebih dalam sangat perlu memahami konsep dari setiap bagian terlebih dahulu yakni konsep tentang manusia, Tuhan dan kemanunggalan.

\section{Konsep tentang Manusia}

Ajaran tentang manusia dalam Kejawen merupakan titik sentral. Maksudnya di sini adalah ajaran Kejawen muncul sebagai manifestasi dari kerinduan manusia untuk memperoleh keselamatan dan kebahagiaan hidup (Endraswara, 2011). Keselamatan yang dimaksudkan tidak hanya mencakup keselamatan di dunia melainkan juga keselamatan abadi. Oleh karena itu, konsep ini tidak dapat dipisahkan dari tujuan manusia itu sendiri dalam mencapai keselamatan dan kebahagiaan hidup.

Ajaran Kejawen memahami manusia sebagai makhluk Tuhan. Maksudnya di sini adalah keberadaan manusia di dunia ini diciptakan oleh Tuhan. Endraswara mengemukakan bahwa awal mulanya manusia tidak ada namun karena karsa dan kreasi Tuhan manusia menjadi ada 
(Endraswara, 2011). Pendapat Endraswara secara tidak langsung menujukkan keberadaan manusia disebabkan oleh karya Tuhan. Bertolak dari statusnya sebagai kreasi Allah, hal ini menunjukkan bahwa manusia berada di bawah dan tunduk pada otoritas ilahi. Dengan demikian, secara sederhana manusia dalam pemahaman Kejawen merupakan makhluk, hamba atau abdi Tuhan.

Sebagai abdi Tuhan, manusia memiliki tujuan mencapai keselamatan jiwa dan raga. Pencapaian jiwa dan raga di sini dapat dipahami pengalaman menyatu dengan Tuhan (Manunggaling Kawula Gusti). Heniy Astiyanto melihat keselamatan jiwa dan raga dapat ditempuh dengan ketaatan pada syariat, tarekat, hakikat serta makrifat. Baginya, laku lahir tidak boleh menyimpang dari syariat dan tarekat, sedangkan laku batin tidak boleh menyimpang dari hakikat dan makrifat (Astiyanto, 2012). Astiyanto sedang menjelaskan bahwa keselamatan jiwa dan raga manusia merupakan sebuah proses yang berlangsung seumur hidup.

Pada dasarnya, pemahaman Kejawen tentang manusia tidak dapat dipisahkan dari otoritas terhadap alam. Allah disebut makrokosmos dan manusia sebagai mikrokosmos. Sebagai mikrokosmos, manusia tidak terlepas dari ketentuan makrokosmos sekalipun untuk melihat ketentuan kosmos secara keseluruhan dapat bertolak dari dirinya sendiri (Subandrijo, 2000). Artinya di sini adalah manusia memiliki otoritas untuk mengatur kelangsungan dunia namun juga harus tunduk pada otoritas 
Ilahi. Dengan kata lain, ketika manusia memiliki otoritas untuk mengatur dunia maka pada saat yang sama juga menjadi Tuhan atas dunia. Jadi, penekanan di sini bukan pada kesamaan dalam wujud tetapi pada otoritas yang dimiliki.

\section{Konsep tentang Tuhan}

Pemahaman Kejawen tentang Tuhan masih ambivalen. Artinya, pemahaman Kejawen tentang Tuhan masih menganut transendensi dan imanensi. Allah dalam posisi Transenden karena Kejawen mempercayai Tuhan adalah mutlak dan sudah ada sebelum yang lain ada, sedangkan Allah dalam posisi imanen karena kehadirannya di alam semesta dan di dalam diri manusia (Endraswara, 2003).

Pada dasarnya, pemahaman Kejawen tentang Tuhan dipengaruhi oleh Monisme Panteistik timur. Monisme merupakan konsep yang mempercayai bahwa ada satu substansi dalam alam (Zoetmulder, 1995). Jika hanya ada satu substansi maka Allah dan dunia merupakan satu kesatuan. Artinya, dunia adalah Allah dan Allah adalah dunia. Jika demikian, Allah bukan lagi personal melainkan substansi, kekuatan dan hukum yang dikombinasikan dalam manifestasi alam semesta yang ada. Di lain sisi, panteisme merupakan konsep yang memahami bahwa dunia (kosmos) ini adalah Tuhan dan Tuhan merupakan pusat dari segala kosmos (Endraswara, 2011). Segala yang ada di dalam dunia merupakan bagian dari Tuhan. Pengertian ini membawa kepada pemahaman bahwa 
tidak ada lagi perbedaan antara Tuhan sebagai pencipta dan dunia sebagai ciptaan.

Pada dasarnya, di antara monisme dan panteisme terdapat hubungan. Panteisme merupakan bentuk monisme dalam menetapkan ketunggalan segala sesuatu berpangkal pada Tuhan. Zoetmulder menuliskan monisme dalam arti sempit berada di sisi yang berbeda dengan panteisme. Meskipun ada perbedaan, diantara keduanya juga terdapat keterkaitan satu dengan yang lain. la menegaskan:

Dalam panteisme, dunia telebur dalam Tuhan. Dengan salah satu cara dunia merupakan bagian dari hakikatNya. Di dalam monisme, Tuhan terlebur dalam dunia. Dunia merupakan ada yang tunggal dan mutlak. Bermula dari sifat yang mutlak, dunia masih dapat disebut dengan nama Tuhan (Zoetmulder, 1995, p. 3).

Dengan demikian, monisme dan panteisme pada dasarnya berakar pada pendapat bahwa segala sesuatu tunggal dalam adanya perbedaan. Panteisme menekankan segala sesuatu yang berada di atas alam kebendaan sedangkan monisme bersifat religius dan bersifat materialistis (Endraswara, 2012).

Monisme dan panteisme mengalami perkembangan di dalam budaya Kejawen. Panteisme lebih menekankan otoritas Tuhan atas dunia. Tuhan memiliki otoritas tertinggi di atas segalanya karena la adalah pengendali dunia (Endraswara, 2003). Pemahaman ini bermula dari ide bahwa Tuhan ada di dalam diri manusia dan tanpa Tuhan segala sesuatu tidak akan eksis. Dari pengertian yang ada dapat dipahami bahwa panteisme lebih menekankan otoritas terbesar yang dimiliki Tuhan. 
Monisme lebih melihat otoritas terbesar ada di dalam diri manusia. Monisme memahami Tuhan merupakan prinsip yang menyatukan dan ada di dalam manusia (Endraswara, 2003). Sekalipun kuasa tersebut berasal dari Tuhan, monisme lebih menekankan sisi manusia sebagai bagian didalamnya. Oleh karena itu, kehadiran manusia sangat penting di dalam paham ini.

Petir Abimayu menuliskan bahwa konsep Kejawen tentang Tuhan tidak dapat dilepaskan dari siapa yang disembah (sesembahan), siapa yang menyembah dan bagaimana cara menyembahnya (panembah) (Abimanyu, 2014). Hal ini menunjukkan bahwa konsep Tuhan dapat dilihat dari dua arah yakni okum dan cara. Oknum yang dimaksudkan disini dapat dipastikan bahwa yang disembah adalah Tuhan dan yang menyembah adalah manusia. Mengenai cara, panembah merupakan memberikan sesuatu kepada Tuhan. Soesilo menuliskan bahwa cara menyembah dapat dilakukan dalam tiga cara.

Pertama, Sembah Raga. Sembah ini biasa disebut sembah Sarengat yang mengutamakan gerakan raga dengan cara yang sudah ditentukan menurut pahamnya sendiri-sendiri dan disertai doa. Kedua, Sembah Cipta. Di dalam sembah ini, seseorang mengutarakan sarana cipta untuk mendekat kepada Allah, berupa rangkaian doa. Ketiga, Sembah Rasa. Sembah rasa biasa disebut dengan sembah kalbu, di mana hati manusia ialah jantung yang menjadi pusat rasa (Soesilo, 2004, pp. 40-41).

Soesilo sedang menjelaskan bahwa panembah didasarkan pada unsur hidup manusia yakni raga atau jasmani, cipta atau pikiran dan rasa atau jiwa. 
Konsep tentang Manunggal

Manunggal dalam Manunggaling Kawula Gusti merupakan penyatuan antara Tuhan dengan manusia. Penyatuan tersebut dapat dilihat sebagai peleburan sifat manusiawi dan bersatu dengan Tuhan (Nugroho, 2005). Pemahaman ini dapat dilihat bahwa penyatuan manusia dengan Tuhan hanya dalam hal sifat dan karakter saja. Jadi, manusia meleburkan sifat dirinya menjadi satu dengan Tuhan.

Jika manusia melebur dengan Tuhan dalam hal sifat karakter, bagaimana cara mereka melakukannya? Penyatuan manusia dengan Tuhan dapat dengan dua cara yakni mendekatkan diri dengan ritual ibadah dan ajaran mistis (Utomo, 2017). Dengan dua cara ini, seseorang dapat semakin mendekatkan diri kepada Tuhan hingga pada akhirnya terjadinya sebuah penyatuan.

Sindung Haryanto memiliki pandangan berbeda mengenai tahapan manusia dalam melebur dengan Tuhan. Menurutnya, seseorang harus dapat melewati beberapa tahapan untuk mencapai kondisi kemanunggalan.

Tahap awal adalah syariat, merupakan tahapan di mana seseorang mematuhi segala norma agama dengan sungguh-sungguh. Tahap kedua, tarikat di mana merupakan seseorang bertobat dan menyesali segala dosanya. Tahap ketiga adalah hakikat di mana seseorang mengenal Tuhan melewati doa, dzikir, mawas diri dan menghindari kesenangan dunia. Tahap keempat adalah makrifat di mana manusia telah mencapai "kemanunggalan dengan Tuhan", jiwa manusia berpadu dengan jiwa semesta (Haryanto, 2013, p. 56). 
Fase-fase yang telah dijelaskan menunjukkan bahwa kemanunggalan manusia dengan Tuhan merupakan sebuah proses yang berkelanjutan. Artinya, ketika seseorang menyatu dengan Tuhan maka sebelumnya ia telah mengalami pemurnian sifat dan karakter.

Penjelasan di atas lebih menekankan dari sisi manusia menyatu dengan Tuhan. Bagaimana peleburan yang dilakukan oleh Tuhan dalam kehidupan manusia? Kemanunggalan Tuhan kepada manusia dapat dilihat dari kehadiran Tuhan di dalam hati manusia. Kehadiran tersebut lebih tepatnya di bagian paling halus dalam hati manusia yang dinamakan siir (rahasia) (Zoetmulder, 1995). Keadaan ini dapat menjadi ciri Tuhan di dalam manusia. Jadi, kemanunggalan Tuhan kepada manusia dapat dilihat dari kehadiranNya dalam hati nurani manusia.

Kehadiran Tuhan dalam hati manusia bukanlah hal sepele. Dalam perjalanannya, di hati manusia terdapat hawa nafsu yang merupakan penghalang dari kehadiran Tuhan. Hawa nafsu merupakan penghambat bagi jiwa untuk dapat menuju kesempurnaan hidup, yakni menyatu dengan Tuhan. Sidqi menjelaskan untuk mencapai taraf kesempurnaan, manusia harus membebaskan jiwa dari nafsu yang membelenggu. (Sidqi, 2017)

Penyatuan manusia dan Tuhan dapat terlihat sebuah keselarasan. Manusia dapat menyatukan sifat karakternya dengan Tuhan dengan cara mendekatkan diri melalui ibadah. Begitu juga dengan Tuhan, Tuhan menyatukan dirinya dengan manusia dalam bentuk kehadirannya di dalam 
hati manusia yang bersih. Dengan kata lain, ketika manusia memiliki hati yang bersih maka Tuhan dapat hadir dalam hatinya dan inilah yang dimaksud dengan Manunggaling Kawula Gusti.

\section{Persamaan}

Ada persamaan kemanunggalan yang ditemukan antara di teks Yohanes 15:7 dengan konsep Manunggaling Kawula Gusti. Pertama, kemanunggalan merupakan perubahan hidup manusia semakin dekat atau sama dengan Tuhan. Kemanunggalan dalam Yohanes 15:7 merupakan proses penyatuan manusia dengan Tuhan melalui disiplin rohani. Kemanunggalan di dalam konsep Manuggaling Kawula Gusti merupakan penyatuan manusia dengan Tuhan melalui tahapan pertobatan hidup. Dari kedua sisi ini, kemanunggalan merupakan proses intimasi antara manusia dengan Tuhan melalui perubahan hidup seseorang.

Kedua, kemanunggalan merupakan sesuatu yang melewati tahapan proses. Terjadinya kemanunggalan di dalam Yohanes 15:7 melalui pelaksanaan disiplin rohani yang terus menerus dilakukan. Sedangkan di dalam konsep Manunggaling Kawula Gusti, kemanunggalan terjadi dalam proses perubahan hidup seseorang yang dapat dilihat dari pemikiran, tingkah laku dan perbuatannya. Kedua sisi ini dapat dilihat bahwa kemanunggalan dengan Tuhan bukan merupakan sesuatu yang instan melainkan melewati tahapan proses yang panjang. 
Ketiga, kemanunggalan merupakan hakikat hidup manusia. Di dalam Yohanes 15:7 dapat dilihat ketika seseorang mengalami kemanunggalan dengan Allah maka hal-hal jasmani bukanlah sesuatu yang penting untuk dikejar. Begitu juga dengan konsep Manunggaling Kawula Gusti di mana ketika seseorang mengalami manunggal dengan Tuhan maka semua yang dimiliki sudah lebih dari cukup. Berdasarkan penjelasan kemanunggalan dan dampak yang diperoleh dapat dilihat bahwa kemanunggalan dengan Tuhan merupakan sesuatu yang penting dalam kehidupan seseorang. Dengan kata lain, kemanunggalan merupakan esesnsi dari tujuan hidup seseorang.

Keempat, ada dampak yang diterima ketika seseorang mencapai kemanunggalan. Yohanes 15:7 menunjukkan seseorang yang mengalami kemanunggalan dengan Tuhan maka segala sesuatu yang diinginkan akan diperoleh. Begitu juga dalam konsep Manunggaling Kawula Gusti, ketika seseorang manunggal dengan Allah maka ia akan merasakan ketentraman batin.

\section{Perbedaan}

Ada perbedaan yang di dapatkan dari kemanunggalan dalam teks Yohanes 15:7 dengan konsep Manunggaling Kawula Gusti. Pertama, proses kemanunggalan itu sendiri. Meskipun esensi dari kemanunggalan adalah proses penyatuan dengan Tuhan, namun proses mencapai kemanunggalan dari dua sisi mengalami perbedaan. Kemanunggalan dalam Yohanes 15:7 dapat dicapai bila seseorang melakukan disiplin 
rohani. Sedangkan di dalam konsep Manunggaling Kawula Gusti, kemanunggalan diperoleh ketika seseorang melewati tahap-tahap perubahan hidup.

\section{PEMBAHASAN}

\section{Kemanunggalan Merupakan Tujuan Hidup Manusia}

Kemanunggalan merupakan sesuatu hal yang penting atau harus dikejar. Yohanes 15:7 dan Konsep Manunggaling Kawula Gusti menjelaskan bahwa kemanunggalan merupakan tujuan hidup yang sesungguhnya. Hal ini dapat dilihat tujuan hidup dalam agama Kristen yang mengajarkan supaya orang percaya hidup bertumbuh di dalam Tuhan melalui disiplin rohani yang dilakukan berulang-ulang kali. Pelaksanaan disiplin rohani yang konsisten dapat membantu kehidupan spiritual yaitu menyatu dengan Tuhan (Djadi, 2012). Begitu juga dengan Konsep Manunggaling Kawula Gusti, bagi penganut Kejawen, kehidupan manusia yang sejati terjadi ketika ia dapat menyatu dengan Tuhan melalui beberapa proses perubahan hidup. Jadi, kemanunggalan seseorang dengan Tuhan dalam agama Kristen dan Kejawen merupakan tanda seseorang sudah mencapai tujuan hidupnya.

\section{Kemanunggalan Merupakan Kebutuhan Tertinggi Manusia}

Ketika seseorang mengalami kemanunggalan dengan Tuhan, secara tidak langsung kebutuhan tertingginya telah terpenuhi. Semua dapat dilihat di mana seseorang yang manunggal dengan Tuhan akan 
senantiasa mensyukuri semua yang dimilikinya. Mengapa demikian? Hal ini karena ketika seseorang mengalami kemanunggalan dengan Tuhan maka ia akan merasa semua yang ada dalam kehidupannya sudah lebih dari cukup.

\section{KESIMPULAN}

Kemanungalan di dalam Yohanes 15:7 dengan dalam konsep Manunggaling Kawula Gusti memiliki kesamaan. Kemanunggalan di dalam Yohanes 15:7 merupakan penyatuan manusia dengan Tuhan yang dilihat dari kedewasaan karakter, pola pikir dan tindakan dengan melakukan disiplin rohani secara konsisten. Kemanunggalan di dalam konsep Manunggaling Kawula Gusti merupakan proses penyatuan manusia dengan Tuhan yang terjadi melalui proses perubahan hidup seseorang.

Kemanunggalan di dalam Yohanes 15:7 dan Manunggaling Kawula Gusti juga melihat kemanunggalan dengan Tuhan merupakan tujuan hidup manusia. Warisman Harefa menuliskan penyatuan manusia dengan Tuhan merupakan kesatuan yang permanen di mana tidak mengandung kesatuan dalam subtansi melainkan menjaga perbedaan individualitas antara Kristus dan orang percaya (Harefa, 2018). Harefa sedang menjelaskan bahwa penyatuan orang percaya dengan Kristus merupakan penyatuan meliputi karakter. Artinya, orang percaya yang hidup di dalam Tuhan akan memiliki sifat, pola pikir, karakter ilahi. Kemanunggalan di dalam Manunggaling Kawula Gusti sebagai penyatuan dengan Tuhan 
melalui proses perubahan hidup yakni syariat, tarikat, hakikat dan makrifat. Pada akhirnya, setiap orang yang menyatu dengan Tuhan akan merasakan ketenangan hidup. Jadi, dengan adanya kesamaan kemanunggalan dalam Yohanes 15:7 dan Manunggaling Kawula Gusti dapat menjadi misi kontekstual kepada penganut Kejawen. Kemanunggalan dapat menjadi kesempatan terciptanya toleransi antara penganut agama Kristen dan penganut Kejawen.

\section{DAFTAR PUSTAKA}

Abimanyu, P. (2014). Mistik kejawen : menguak rahasia hidup orang Jawa. Yogyakarta: Palapa.

Astiyanto, H. (2012). Filsafat Jawa: Menggali Butir-butir Kearifan Lokal. Yogyakarta: Warta Pustaka.

Bruner, F. D. (2012). The Gospel of John : a commentary. Grand Rapids, Michigan: W.B. Eerdmans Pub. Co.

Burge, G. M. (2009). John: from biblical text to contemporary life. Grand Rapids Michigan: Zondervan.

Carter, M., Wredberg, J., Platt, D., Akin, D. L., \& Merida, T. (2017). Exalting Jesus in John. Nashville-Tennessee: Holman Reference.

Djadi, J. (2012). Spiritual Seorang Pelayan Tuhan. Jurnal Jaffray, 10(1), 110-117. https://doi.org/10.25278/jj71.v10i1.66

Endraswara, S. (2003). Mistik Kejawen. Yogyakarta: Lembu Jawa.

Endraswara, S. (2011). Kebatinan Jawa dan jagad mistik kejawen. Yogyakarta: Lembu Jawa.

Endraswara, S. (2012). Agama Jawa: Laku Batin Menuju Sangkan Paran. Yogyakarta: Lembu Jawa.

Hadiwijaya. (2010). Tokoh-tokoh Kejawen. Yogyakarta: Kelompok 
Penerbit Pinus.

Harefa, W. (2018). Keunikan Kekristenan Berakar di Dalam Kesatuannya Dengan Kristus. Kurios, 2(1), 32-45. https://doi.org/10.30995/kur.v2i1.19

Haryanto, S. (2013). Dunia Simbol Orang Jawa. Yogyakarta: Kepel Press.

Henry, M. (2008). Matthew Henry's commentary on the whole Bible: complete and unabridged. Hendickson Publishers.

Klink, E. W. (2016). John : Zondervan exegetical commentary on the New Testament. Grand Rapids Michigan: Zondervan Publisher.

Kresna. (2014, June 1). Kebanggaan menjadi pengabdi Kraton Yogyakarta. Merdeka.Com. Retrieved from https://www.merdeka.com/peristiwa/kebanggaan-menjadi-pengabdikraton-yogyakarta.html

Nugroho, S. Y. (2005). Semar dan Filsafat Ketuhanan. Yogyakarta: Gelombang Pasang.

Sidqi, A. (2017). MENDARAS MANUNGGALING KAWULA GUSTI SYEKH SITI JENAR. Dinamika Penelitian: Media Komunikasi Penelitian Sosial Keagamaan, 17(1), 1-26. https://doi.org/10.21274/dinamika.2017.17.1.1-26

Soesilo. (2004). Kejawen: Philosofi dan Perilaku. Jakarta: Yayasan Yusula.

Subandrijo, B. (2000). Keselamatan bagi orang Jawa. BPK Gunung Mulia.

Sudaryanto, A. (2018). Hak dan Kewajiban Abdi Dalem Dalam Pemerintahan Kraton Yogyakarta. Mimbar Hukum, 20(1), 163-177.

Sugiyono. (2016). Memahami Penelitian Kualitatif. Bandung: Alfabeta.

Supriyadi, S. (2016). Community of Practitioners: Solusi Alternatif Berbagi Pengetahuan antar Pustakawan. Lentera Pustaka: Jurnal Kajian IImu Perpustakaan, Informasi Dan Kearsipan, 2(2), 83-93. https://doi.org/10.14710/lenpust.v2i2.13476

Tenney, M. C. (2003). Injil Iman : suatu telaah naskah Injil Yohanes secara analitis. Malang: Gandum Mas. 
Utomo, A. H. (2017). Tauhid Al-Wujud Syeikh Siti Jenar dan Unio Mystica Bima. Jurnal Filsafat, 40(2), 116-127. https://doi.org/10.22146/jf.23204

Wenham, J. W. (2003). Bahasa Yunani Koine. Malang: SAAT.

White, J. F. (2011). Pengantar Ibadah Kristen. Jakarta: BPK Gunung Mulia.

Wreksosoehardjo, S. (2009). Rasa Lan Panggraita; Intisati Ajaran dan Kearifan Jawa. Semarang: Fasindo Press.

Zoetmulder, P. J. (Petrus J. (1995). Manunggaling kawula Gusti: pantheïsme dan monisme dalam sastra suluk Jawa: suatu studi filsafat. Hasil kerja sama Perwakilan Koninklijk Instituut voor Taal-, Land-, en Volkenkunde dengan Lembaga IImu Pengetahuan Indonesian bersama Penerbit PT Gramedia. 